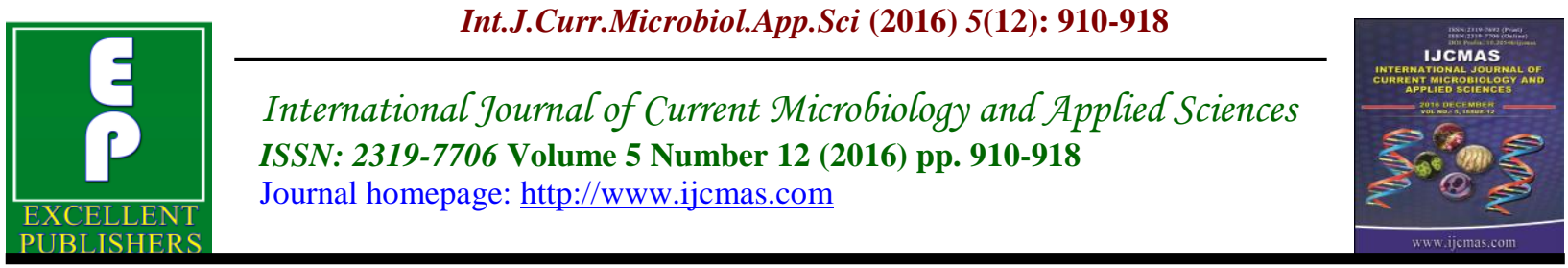

Original Research Article

http://dx.doi.org/10.20546/ijcmas.2016.512.099

\title{
A Study on Impact of Agronomical Carbon Sources in Bacterially Produced PHA
}

\author{
R. Kalaivani* \\ Department of Botany and Biotechnology, Bon Secours College for women, \\ Thanjavur, TamilNadu, India \\ *Corresponding author
}

\begin{abstract}
A B S T R A C T
Keywords

Green house emission, PHA, fermentation, agronomical byproducts, carbon source.

\section{Article Info}

Accepted:

20 November 2016

Available Online:

10 December 2016

Addiction on conventional plastics and their illimitable usage have resulted in waste accumulation and greenhouse gas emissions. Recent technologies are rapt headed for the development of bio-green materials in order to protect our environment. A biologically-synthesized plastic, polyhydroxyalkanoate (PHA) has been a major hope due to its similar physical properties to synthetic plastics. The selections of suitable bacterial strains, inexpensive carbon sources, efficient fermentation and recovery processes are important aspects that should be taken into consideration for the commercialization of PHA. This study is intended to utilise available agronomical by-products as carbon source to accumulate more PHA by bacterial isolate KSN5 Bacillus sp. In this present study molasses, coir pith, coconut oil cake, paddy chaff and vermicompost were used at various concentration. In present study among the different carbon sources utilized, the bacterial isolate KSN5 Bacillus sp. accumulated $95 \%$ (CDW $20.54 \pm 0.14 \mathrm{~g} / \mathrm{L}$ ) PHA in presence of $4 \%$ molasses. Next to that, the medium supplemented with coconut oil cake was found to be a substrate for growth and PHA accumulation.
\end{abstract}

\section{Introduction}

Environment protection and sustainable product development has been our target for last few years, and there has been an extensive research going on at various ways. Consequently, biodegradable plastic for example Polyhydroxyalkaonates (PHA) seems to be a significant polymer almost equal to plastics. PHA, a polyester compound, is becoming more interesting among the group of biodegradable plastics.

This polymer has a wide range of potential applications because of its desired features such as biocompatibility, biodegradability, naturally accumulated by several bacterial species and negligible cytotoxicity to the cells. Hence, the potential application of PHA is being attained recognition in various fields involving packaging, medical and coating materials. These desirable properties in compounding and blending have broadened their applications.

One of the most important difficulties in the commercialization of PHA is the high production cost when compared to those 
from the production of petrochemical-based plastic materials. From an industrial process point of view, the optimal PHA producing microbial strains should fulfil many requirements such as high accumulation rates, ability to utilize cheap carbon sources and fast growth.

Castilho et al., (2009) stated that the market price of commercially available PHA (approximately 10 to $12 €$ per $\mathrm{kg}$ ) is relatively greater than that of conventional synthetic plastics. The high manufacturing costs involved during the production of these polymers is mainly responsible for hampering the commercialization of biodegradable plastics. The major factors affecting the overall economics of PHA production are its content, yield and productivity, the cost of the raw materials and the recovery methods. Among these various factors, the raw material costs dominate the manufacturing costs said by Van-Thouc et al., (2008). Therefore, for economical PHA production inexpensive substrates that can be used as carbon sources for bacterial strains to synthesize large quantities of intracellular PHA are necessary. By-products such as molasses, straw, bagasse generated in the agricultural sector are available abundantly and are generally used as cattle feed since they have little economic value. These agricultural residues are rich in carbohydrates and the use of such materials for the synthesis of value-added products can be advantageous and also contribute significantly to the reduction of their disposal costs (Thomsen, 2005; Castilho et al., (2009).

The identification of alternative costeffective substrates for the production of PHA has become an important objective for the commercialization in this research. By utilizing some agronomical by-products available at Thanjavur District, the present study enhanced the accumulation of PHA.

\section{Materials and Methods}

\section{Sampling sites}

In Thanjavur district, molasses, coir pith, coconut oil cake, paddy chaff and vermicompost are available more and used as cattle feed, fuel and manure in rural areas. As they contain more carbon content in different form, they were used in the present study as a crude carbon source after hydrolysis for PHA production. The afore said wastes were collected from Arignar anna sugar factory, Kurungulam, Coir factory, at Vallam, local oil mill, Indian Paddy processing unit and Sriamman Biocare, Thanjavur respectively.

\section{Source optimization}

\section{Characterization of agronomical by products}

The selected substrates were characterized for moisture content, total sugar, total reducing sugar $\mathrm{C} \%, \mathrm{~N} \%$ and $\mathrm{pH}$. Total sugars were estimated using the Anthrone method (Dreywood, 1946). The amount of total reducing sugars was the key aspect for the selection of the substrates. The total reducing sugars were estimated by Dinitrosalicylic acid method (DNS) Method (Miller, 1959). The carbon and nitrogen content was determined using the CNSanalyzer (IICPT, Thanjavur). $\mathrm{pH}$ and the moisture content were estimated as given below.

\section{Moisture}

A clean and empty silica crucible was heated at $103{ }^{\circ} \mathrm{C}$ to $105{ }^{\circ} \mathrm{C}$ for an hour in a hot air oven and allowed to cool down to room temperature in desiccators and weighed. All the afore said carbon sources i.e substrate $(10 \mathrm{~g})$ was weighed accurately in the silica crucible and dried at $103{ }^{\circ} \mathrm{C}$ to 
$105^{\circ} \mathrm{C}$ to a constant weight. Moisture content was calculated. The dried samples were retained for further analysis.

\section{pH}

The $\mathrm{pH}$ of waste extracts were checked using Orion $\mathrm{pH}$ meter after calibrating the instrument with standard $\mathrm{pH}$ buffers.

Pretreatment and processing of the agronomical by-products

All the by-products were collected in a sterile container and washed in water then sun dried for two days. All were dried at $80^{\circ} \mathrm{C}$ for overnight in hot air oven. Each dried sample was ground to fine powder and passed through a 35-mesh sieve. Concentration of cellulose, hemicellulose and lignin were estimated (Updegraff, 1969; Goering and Vansoest, 1970). Each waste was first partially delignified by autoclaving $\left(120^{\circ} \mathrm{C}, 15 \mathrm{lb}, 20 \mathrm{~min}\right)$. The mixture was kept at room temperature $\left(37 \pm 2{ }^{\circ} \mathrm{C}\right)$ for $24 \mathrm{~h}$. They were hydrolyzed by $0.5-5 \% \mathrm{v} / \mathrm{v}$ sulphuric acid (solid: liquid (1:10-1:20) and autoclaved at $121^{\circ} \mathrm{C}$, and 15 psi for $30 \mathrm{~min}$. The hydrolyzed samples were filtered and supernatants were neutralized using sodium hydroxide $(6 \mathrm{~N})$.

\section{Total sugar}

Anthrone solution was prepared by dissolving $0.1 \mathrm{~g}$ of Anthrone (9,10-dihydro 9 Ozoanthracene) in $76 \%$ sulphuric acid to a volume of $100 \mathrm{ml}$. Glucose stock standard solution was prepared in double distilled water by dissolving $10 \mathrm{mg}$ of glucose in 1 $\mathrm{ml}$ and making a working stock of $1 \mathrm{mg} \mathrm{ml-}$ 1. The standard stock solution was taken in aliquots of $0.5, \quad 1.0,1.5,2,2.5$, corresponding to $50,100,150,200$ and 250 $\mu \mathrm{g}$ of glucose respectively in test tubes and the final volume was made to $5 \mathrm{ml}$ by adding distilled water. A reagent blank was also run along with the standards. All the tubes were transferred to an ice bath and $10 \mathrm{ml}$ ice-cold anthrone reagent was added to each of the tubes gradually. Afterwards the tubes were kept in boiling water bath for 16 min. The tubes were then transferred to an ice bath and allowed to stand for 10 minutes at room temperature. The blue green colour developed was read for absorbance at 620 $\mathrm{nm}$ of wavelength using a Spectrophotometer (U-2000, Hitachi, Japan).

\section{Reducing sugar}

The DNS method was followed for estimating the concentration of reducing sugars (G. Miller, 1959). Standard solution in the range of 0 to $2 \mathrm{ml}$ was pipetted out. The final volume in all the tubes was made up to $2 \mathrm{~mL}$ with distilled water concentrations ranging from 0 to $750 \mathrm{mg} .1$ $\mathrm{mL}$ DNS reagent was added to all the test tubes and mixed well. The capped test tubes were kept in a boiling water bath for 10 minutes. The tubes were taken and cool to room temperature. Extinction at $540 \mathrm{~mm}$ was read against the blank. Standard curves of the sugars were prepared to estimate the concentration of the unknowns.

\section{Mass production of PHA by constructive bacterial isolate}

Optimum concentration of the hydrolysate was determined by incubating $5 \%$ (V/V) of the culture in PY medium (Glucose - 20g, Peptone - 5g, Yeast extract - 3g, Agar - 15g, Distilled water- $1000 \mathrm{ml}$ ) with 1 to $5 \%$ hydrolysates of agronomical carbon sources and incubated at room temperature for 48 to $72 \mathrm{hrs}$ on shaker incubator. Then the bacterial isolate culture was inoculated in the PY medium and incubated at room temperature for 48 to $72 \mathrm{hrs}$ on shaker incubator. 


\section{Extraction and quantitative assay}

The spectrometric chemical assay for the determination of PHA from the sample was estimated by using Law and Slepecky, 1961 method. Suspension of the culture was centrifuged at 10,000rpm for $15 \mathrm{~min}$. The pellet was re-suspended in a volume of $30 \%$ sodium hypochloride equal to the original volume of suspension at $37^{\circ} \mathrm{C}$ for $20 \mathrm{~min}$. After 1 hour at $37^{\circ} \mathrm{C}$, the lipid granules were centrifuged, washed with water and then washed with Acetone and Ethanol. The polymer was dissolved in chloroform and kept for complete evaporation. Then $5 \mathrm{ml}$ of concentrated $\mathrm{H}_{2} \mathrm{SO}_{4}$ was added and heated for $40 \mathrm{~min}$ at $100^{\circ} \mathrm{C}$ in a water bath. The resultant crotonic acid was measured at 235nm against $\mathrm{H}_{2} \mathrm{SO}_{4}$ as blank in UV -VIS spectrophotometer (Beckman DU 40). Residual biomass was estimated as the difference between dry cell weight and dry weight of extracted PHA (Zakaria et al., 2010). The dried power of PHA was calculated by the formula given below.

Residual biomass $(\mathrm{g} / \mathrm{L})=\mathrm{DCW}(\mathrm{g} / \mathrm{L})-$ Dry weight of extracted PHA $(\mathrm{g} / \mathrm{L})$.

PHA accumulation $(\%)=$ Dry weight of extracted PHA $(\mathrm{g} / \mathrm{L}) \times 100 \%$

$\mathrm{CDW}(\mathrm{g} / \mathrm{L})$

Then the PHA quantification procedure was followed as above mentioned.

\section{Results and Discussion}

Analysis of the physico-chemical
parameters of the agronomical by-
products

All the agronomical by-products were evaluated for their physical characteristics with respect to colour, smell, form, texture, specifically $\mathrm{pH}$ and moisture content might influencing the utility by bacterial isolate (Table 1). Expect molasses, all other wastes were in dry condition. The $\mathrm{pH}$ of all the byproducts was observed almost below $\mathrm{pH}$ 7.0. In vermicompost, it was found as 7.0-8.2. $30.36 \%$ of moisture content was observed in vermi compost and $22.5 \%$ in molasses. $0.95 \%, 5.54 \%, 3.70 \%$ of moisture content, was observed in coir pith, rice chaff, and coconut oil cake respectively.

High moisture content was observed with molasses as compared with the other agricultural by-products. Therefore this waste needs to be dried before storage to elude growth of unwanted microorganisms. The $\mathrm{pH}$ of all the by-products was below $\mathrm{pH}$ 7.0 proposing the acidic nature of these wastes.

Chemical composition of the agronomical by products was estimated and presented in Table 2. The amount of total reducing sugars was the key aspect for the selection of the substrates. A high percentage of this carbon is in the form of carbohydrates as seen from the total sugar content of these residues.

The presence of reducing sugar was estimated as $0.32 \mathrm{~g} / \mathrm{L}, \quad 0.164 \mathrm{~g} / \mathrm{L}$, in molasses and coconut oil cake respectively. The total sugar was estimated in molasses as $0.854 \mathrm{~g} / \mathrm{L}, 0.0227 \mathrm{~g} / \mathrm{L}$ in Coir pith, 0.06 in rice chaff, and 0.778 in coconut oil cake were observed. In vermicompost, there was no significant amount of reducing sugar present. All the by-products designated were rich in carbon content, i.e. $54.2 \%$ in coconut oil cake, $50.2 \%$ in rice chaff, $47 \%$ in molasses, $45.8 \%$ in coir pith and $21.7 \%$ in vermicompost were observed. 
A high percentage of this carbon is in the form of carbohydrates as seen from the total sugar content of these residues. In case of molasses and coconut oil cake, significant amount of total sugars was found even though presence of more than $40 \%$ of carbon in these by-products was estimated. Coconut oil cake consists of $4.8 \%$ nitrogen content. In vermicompost, $1.84 \%$, rice chaff, $1.4 \%$ and in molasses $0.4 \%$ of nitrogen content were observed. In coir pith there nitrogen content was not found significantly. In case of rice chaff, insignificant amount of total sugars was found even though presence of more than $40 \%$ of carbon in these by-products was estimated. The weak growth of the isolates and their inability to utilize these by-products can be documented to the presence of carbon in a form not metabolizable by the isolates.

\section{Mass production of PHA by utilizing agronomical by-products}

In present study among the different carbon sources utilized, the bacterial isolate KSN5 Bacillus sp. accumulated 95\% (CDW $20.54 \pm 0.14 \mathrm{~g} / \mathrm{L})$ PHA in presence of $4 \%$ molasses (Table 3) and 86.26\% (CDW $18.14 \pm 0.01 \mathrm{~g} / \mathrm{L})$ in presence of coconut oil cake at $5 \%$. In the medium supplemented with rice chaff, KSN5 Bacillus sp. accumulated $68.24 \%$ respectively. Among the different concentrations of coir hydrolysate experienced, the maximum yield was noted in medium containing $3 \%$ of the coir hydrolysate. KSN5 Bacillus sp. showed $38.46 \%$ (CDW $6.42 \pm 0.15 \mathrm{~g} / \mathrm{L}$ ) and $49.89 \%$ (CDW9.41 $\pm 0.01 \mathrm{~g} / \mathrm{L}) \mathrm{PHA}$ in presence of vermicompost at 3\%. However, the growth of the isolates was slow in presence of rice chaff; the isolates were able to accumulate PHA upto $(68.24 \%)$ by KSN5 Bacillus sp. followed by coconut oil cake. It may produces more based on prolonged incubation. The medium supplemented with vermicompost produced $49.89 \%$ of PHA and more CDW based on its carbon content as they are the organic manure, enhance the growth. From the experiment, it was observed that molasses could be the best cheap waste carbon substrate. Next to that, the medium supplemented with coconut oil cake was able to serve as a substrate for growth and PHA accumulation.

\section{Impact of the agro-industrial by-products on PHA accumulation}

Among the carbon sources used molasses yielded more PHA and CDW as supported by Prabakaran and Senthilkumar, (2000). Molasses is a sucrose-rich by-product of sugar manufacturing industry as an inexpensive carbon source. It is considered to be an ideal substrate for fermentative processes. Molasses served as an outstanding source of carbon since all the isolates were able to splendidly supplement with it. The enhanced growth and PHA production of the isolates can be credited to the additional nutrients such as vitamins and minerals found in molasses which function as growth factors (Oliveira et al., 2004). Gouda et al., (2001) informed about the maximum PHA production by using $B$. megaterium with cane molasses and glucose as sole carbon sources 40.8 and $39.9 \%$ DCW respectively. B.thuringensisR1 cells were found to accumulate 22.95 and $31.36 \%$ DCW as PHA in the presence of molasses and table sugar, respectively as stated by Rohini et al., (2006).

Albuquerque et al., 2007 reported about strategies for the development of a side stream process for polyhydroxyalkanoate (PHA) production from sugar cane molasses as the best carbon source. Maria Celisa and Nimali Prabhu, 2009 experimentally proved that molasses to be excellent carbon substrates for PHA accumulation by 
Bacillus sp. In the proposed study, molasses was proved as the best carbon source to accumulate more PHA and the bacterial isolate KSN5 Bacillus sp. accumulated 95\% with CDW $20.54 \pm 0.14 \mathrm{~g} / \mathrm{L}$ of PHA.

Recently, a few studies have been conducted using oil cakes such as sesame, mustard and palm under submerged fermentation conditions and bagasse soy cake using solidstate fermentation (Sharma et al., 2007). Medium augmented with coconut oil cake was able to serve as a substrate for growth. Isolate KSN5 accumulated more PHA using this when compared with other agroindustrial residues. Thakor et al., (2005) found the coconut oil as one of the best carbon source for Comamonas testosteroni. As there was high carbon and little nitrogen content present in coconut flour the isolates may able to accumulate PHA. Preliminary evaluation of coconut oil cake, an agroindustrial residue recommended it to be a potential carbon source for PHA production. In our projected experiment, the isolate KSN5Bacillus sp. exhibited maximal biomass (CDW 18.14 $\pm 0.01 \mathrm{~g} / \mathrm{L}$ ) and $86.26 \%$ PHA. The exclusion of adherent fatty acids from the coconut oil cake hydrolysate was attained by a brief hexane wash thereby enabling the high quantification process (Lee et al., 2000; Maria Celisa Santimano et al., 2009).

Table.1 Physical characteristics of agronomical byproducts

\begin{tabular}{|c|c|c|c|c|c|c|c|c|}
\hline $\begin{array}{l}\dot{z} \\
\dot{n}\end{array}$ & Samples & $\frac{\vdots}{0}$ & $\frac{3}{3}$ & $\overline{\bar{g}}$ & 苞 & 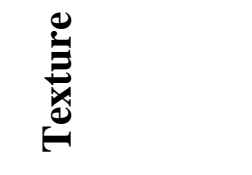 & $\overline{2}$ & $\begin{array}{c}\text { Moisture } \\
\text { Content }\end{array}$ \\
\hline 1 & Molasses & Dark Brown & Wet & Sweet & Syrups & Viscous & $5.5-5.8$ & $22.5 \%$ \\
\hline 2 & Coir pith & brown & dry & sweet & mass & fibrous & $6.5-6.9$ & $0.95 \%$ \\
\hline 3 & Rice chaff & $\begin{array}{c}\text { Golden } \\
\text { brown }\end{array}$ & dry & starchy & $\begin{array}{c}\text { Small } \\
\text { shell }\end{array}$ & fibrous & $6.0-6.5$ & $5.54 \%$ \\
\hline 4 & Coconut oil cake & Grey & dry & oil & mass & granular & $6.0-6.4$ & $3.70 \%$ \\
\hline 5 & Vermi compost & black & dry & organic & mass & Fine granules & $7.0-8.2$ & $30.36 \%$ \\
\hline
\end{tabular}

Table.2 Chemical composition of selected agronomical by -products

\begin{tabular}{|l|l|c|c|c|c|}
\hline $\begin{array}{l}\text { S. } \\
\text { No. }\end{array}$ & \multicolumn{1}{|c|}{ By-products } & $\begin{array}{c}\text { Reducing } \\
\text { Sugar } \\
(\mathbf{g} / \mathbf{L})\end{array}$ & $\begin{array}{c}\text { Total sugar } \\
(\mathbf{g} / \mathbf{L})\end{array}$ & $\begin{array}{c}\text { Carbon } \\
(\mathbf{\%})\end{array}$ & $\begin{array}{c}\text { Nitrogen } \\
(\boldsymbol{\%})\end{array}$ \\
\hline $\mathbf{1}$ & Molasses & 0.32 & 0.854 & 47 & 0.4 \\
\hline $\mathbf{2}$ & Coir pith & Nil & 0.0227 & 45.8 & Nil \\
\hline $\mathbf{3}$ & Rice chaff & Nil & 0.06 & 50.2 & 1.4 \\
\hline $\mathbf{4}$ & Coconut oil cake & 0.164 & 0.778 & 54.2 & 4.8 \\
\hline $\mathbf{5}$ & Vermicompost & Nil & Nil & 21.70 & 1.84 \\
\hline
\end{tabular}


Table.3 Effect of agronomical carbon sources on bacterial isolate KSN5 Bacillus sp.

\begin{tabular}{|c|c|c|c|c|c|c|c|c|c|c|c|}
\hline \multirow{3}{*}{$\begin{array}{l}\text { S. } \\
\text { No. }\end{array}$} & \multirow{3}{*}{$\begin{array}{l}\text { Name of the } \\
\text { Carbon } \\
\text { source }\end{array}$} & \multicolumn{10}{|c|}{$\%$ of carbon source } \\
\hline & & \multicolumn{2}{|c|}{$1 \%$} & \multicolumn{2}{|c|}{$2 \%$} & \multicolumn{2}{|c|}{$3 \%$} & \multicolumn{2}{|c|}{$4 \%$} & \multicolumn{2}{|c|}{$5 \%$} \\
\hline & & $\begin{array}{l}\text { CDW } \\
(\mathrm{g} / \mathrm{L})\end{array}$ & $\begin{array}{l}\text { PHA } \\
(\%)\end{array}$ & $\begin{array}{l}\text { CDW } \\
(\mathrm{g} / \mathrm{L})\end{array}$ & $\begin{array}{l}\text { PHA } \\
(\%)\end{array}$ & $\begin{array}{l}\text { CDW } \\
(\mathrm{g} / \mathrm{L})\end{array}$ & $\begin{array}{c}\text { PHA } \\
(\%)\end{array}$ & $\begin{array}{l}\text { CDW } \\
(\mathrm{g} / \mathrm{L})\end{array}$ & $\begin{array}{c}\text { PHA } \\
(\%)\end{array}$ & $\begin{array}{l}\text { CDW } \\
(\mathrm{g} / \mathrm{L})\end{array}$ & $\begin{array}{c}\text { PHA } \\
(\%)\end{array}$ \\
\hline 1 & Molasses & $\begin{array}{c}2.11 \pm \\
0.11\end{array}$ & 76.24 & $\begin{array}{c}15.21 \pm \\
0.05\end{array}$ & 89.01 & $\begin{array}{c}17.64 \pm \\
0.01\end{array}$ & 92.23 & $\begin{array}{c}20.54 \pm \\
0.14\end{array}$ & 95.01 & $\begin{array}{c}16.12 \pm \\
0.03\end{array}$ & 75.42 \\
\hline 2 & Coir pith & $\begin{array}{c}2.08 \pm \\
0.02 \\
\end{array}$ & 19.12 & $\begin{array}{c}2.55 \pm \\
0.02 \\
\end{array}$ & 31.11 & $\begin{array}{c}6.42 \pm \\
0.15 \\
\end{array}$ & 38.46 & $\begin{array}{c}5.32 \pm \\
0.05 \\
\end{array}$ & 31.81 & $\begin{array}{c}4.16 \pm \\
0.02 \\
\end{array}$ & 28.45 \\
\hline 3 & Rice chaff & $\begin{array}{c}5.87 \pm \\
0.01 \\
\end{array}$ & 42.17 & $\begin{array}{c}8.51 \pm \\
0.11 \\
\end{array}$ & 51.01 & $\begin{array}{c}10.56 \pm \\
0.03 \\
\end{array}$ & 60.12 & $\begin{array}{c}11.57 \pm \\
0.01 \\
\end{array}$ & 68.24 & $\begin{array}{c}9.45 \pm \\
0.10 \\
\end{array}$ & 59.11 \\
\hline 4 & $\begin{array}{c}\text { Coconut oil } \\
\text { cake }\end{array}$ & $\begin{array}{c}9.87 \pm \\
0.25 \\
\end{array}$ & 54.3 & $\begin{array}{c}10.63 \pm \\
0.06\end{array}$ & 61.65 & $\begin{array}{c}16.32 \pm \\
0.12 \\
\end{array}$ & 74.32 & $\begin{array}{c}17.00 \pm \\
0.01 \\
\end{array}$ & 80.11 & $\begin{array}{c}8.41 \pm \\
0.01\end{array}$ & 86.26 \\
\hline 5 & Vermicompost & $\begin{array}{c}5.62 \pm \\
0.01\end{array}$ & 30.99 & $\begin{array}{c}5.57 \pm \\
0.03\end{array}$ & 35.78 & $\begin{array}{c}9.41 \pm \\
0.01\end{array}$ & 49.89 & $\begin{array}{c}8.25 \pm \\
0.11\end{array}$ & 41.30 & $\begin{array}{c}3.47 \pm \\
0.01\end{array}$ & 29.85 \\
\hline
\end{tabular}

Coir pith is a byproduct of the coir processing industry posing disposal problems. Lignocellulose is the most abundant constituent of coir pith and provides simple sugars on hydrolysis. The reducing sugar content in the coir industrial waste hydrolysate was $30 \pm 2.4 \%$.The composition and properties of coir industrial waste vary depending on the maturity of the coconut, method of and disposal, period between extraction and disposal. Coir pith obtained from fully mature nuts has higher amounts of polysaccharides and fewer water soluble salts compared with younger nuts (Savithri and Khan, 1994). Murugesan and Sathesh Prabu, 2010 studied, different concentrations of coir hydrolysate oh PHA production, in which the maximum yield was noted in medium containing $3 \%$ of the coir hydrolysate. In our planned study, among the different concentrations of coir hydrolysate tried, the maximum yield was noted in medium containing $3 \%$ of the coir hydrolysate. KSN5Bacillus sp. showed $6.42 \pm 0.15 \mathrm{~g} / \mathrm{L}$ CDW with $38.46 \%$ of PHA. The isolate was capable of growing on rice chaff when individually supplied as sole carbon sources. In present research, KSN5 Bacillus sp. accumulated 68.24\% PHA with $11.57 \pm 0.01 \mathrm{~g} / \mathrm{L} \mathrm{CDW}$ when compared with other isolates. However, the growth of the isolates was slow the isolates were able to accumulate little amount of PHA followed by coconut oilcake. It also may produce more PHA based on prolonged incubation.

The medium supplemented with Vermicompost, KSN5 Bacillus sp. produced $49.89 \%$ of PHA and more CDW $(9.41 \pm 0.01 \mathrm{~g} / \mathrm{L})$ based on its carbon content. As they are the organic manure, they may enhance the growth rate than PHA accumulation. In this present study, when compared with other carbon sources used, obtained PHA content was low in presence of vermicompost, it might be due to the absence of significant sugar content. Further, hydrolysis of these agro industrial by-products by using dilute acid not only improved the ability of the isolates to assimilate the released fermentable sugars to accumulate PHA but also avoided the interference caused by the insolubles present in the wastes during downstream processing. 
This approach might be influence the accumulation of more PHA by bacterial isolates.

The potential applications of PHA in various industries and in the medical field are hopeful. However, the production cost of PHA has been a major hitch. Consequently, the ongoing commercialization activities concentrate more in isolation of potent microbial strains, creating new types of recombinant strains, tailoring various kinds of PHA, renewable carbon resources and refined recovery processes.

\section{Acknowledgement}

I thank $\mathrm{R}$ \& $\mathrm{D}$ Centre of Bharathiar University, Coimbatore, Tamil Nadu to fulfill this work as a part of my research.

\section{References}

Albuquerque, M.G.E., Eiroa, M., Torres, C., Nunes, B.R., Reis, M.A.M. 2007. Strategies for the development of a side stream process for polyhydroxyalkanoate (PHA) production from sugar cane molasses. J. Biotechnol., 130: 411-421.

Castilho, L.R., Mitchell, D.A. and Freire, D.M.G. 2009. Production of polyhydroxyalkanoates (PHAs) from waste materials and by-products by submerged and solid-state fermentation. Biores. Technol., 100: 5996-6009.

Dreywood, R. 1946. Qualitative test for carbohydrate material. Ind. Eng. Chem. Anal., 18: 499.

Goering, H.K. and Vansoest, P.J. 1970. Forage Analysis. Agriculture Hand book No.379.

Gouda, M.K., Swellam, A.E., Omar, S.H., 2001. Production of PHB by a Bacillus megaterium strain using sugarcane molasses and corn steep liquor as sole carbon and nitrogen sources. Microbiol. Res., 156(3): 2017.

Law, J. and Slepecky, R.A. 1969. Assay of poly- $\beta$-hydroxybutyric acid. $J$. Bacteriol., 82: 52-55.

Lee, M.Y., Park, W.H. and Lenz, R.W., 2000. Hydrophilic bacterial polyesters modified with pendant hydroxyl groups. Polymer, 41: 1703-1709.

Maria Celisa Santimano, A., Nimali Prabhu.T.,2009. PHA Production Using Low-Cost Agro-Industrial Wastes by Bacillus sp. Strain COL1/A6. Res. J. Microbiol., 117119.

Miller, G.L. 1959. Use of dinitrosalicylic acid reagent for determination of reducing sugar. Anal. Chem., 31: 426428.

Murugesan, A.G., Sathesh Prabu, C. 2010. Effective Utilization and Management of Coir industrial waste for the Production of poly- $\beta$ hydroxybutyrate (PHB) using the Bacterium Azotobacter Beijerinickii. Int. J. Environ. Res., 4(3): 519-524.

Oliveira, F.C., Freire, D.M.G. and L.R. Castilho, L.R. 2004. Production of poly(3-hydroxybutyrate) by solid-state fermentation with Ralstonia eutropha. Biotechnol. Lett., 26: 1851-1855.

Rohini, D., Phadnis, S., and Rawal, S.K. 2006. Synthesis and characterization of poly- $\beta$ hydroxybutyrate from Bacillus thuringiensis R1. Indian J. Biotechnol., 5: 276-283.

Savithri, P. and Khan, H.H. 1994. Characteristics of coconut pith and its utilization in agriculture. J. Plant and Crop, 18-22.

Senthilkumar, B., Prabakaran, G., 2006.Production of PHB (bioplastics) using bio-effluent as substrate by 
Alcaligens eutrophus. Ind J. Updegraff, D.M. 1969. Semimicro Biotechnol., 5: 76-79.

Sharma, L., Singh, A.K., Panda, B., Mallick, N. 2007. Process optimization for poly hydroxybutyrate production in a nitrogen fixing cyanobacterium, Nostoc muscorum using response surface methodology. Biores. Technol., 98: 987-993.

Thomsen, M.H. 2005. Complex media from processing of agricultural crops for microbial fermentation. Appl. Microbiol. Biotechnol., 68: 598-606.

Thakor, N., Trivedi, U., Patel, K.C. 2005. Biosynthesis of medium chain length poly(3-hydroxyalkanoates) (mclPHAs) by Comamonas testosteroni during cultivation on vegetable oils Bioresour. Technol, 96: 1843-1850. determination of cellulose in biological materials. Anal. Biochem., 32: 420-424.

Van-Thouc, D., Quillaguaman, J., Mamo, G., Mattiasson, B. 2008. Utilization of agriculture residues for $\operatorname{poly}(3-$ hydroxybutyrate) production by Halomonas boliviensis LC1, J. Appl. Microbiol., 104: 420-428.

Zakaria, M.R., Ariffin, H., Johar, N.A.M., Aziz, S.A., Nishida, H., Shirai, Y. and Hassan, M.A. 2010. Biosynthesis and characterization of poly(3hydroxybutyrate-co hydroxybutyrate) copolymer from wild type Comamonas sp. EB172. Polym. Degrad. Stab., 95: 1382-1386.

\section{How to cite this article:}

Kalaivani, R. 2016. A Study on Impact of Agronomical Carbon Sources in Bacterially Produced PHA. Int.J.Curr.Microbiol.App.Sci. 5(12): 910-918. doi: http://dx.doi.org/10.20546/ijcmas.2016.512.099 